IZA DP No. 7816

Employment Polarization in Spain along the Cycle 1997-2012

Brindusa Anghel

Sara De la Rica

Aitor Lacuesta

December 2013 


\title{
Employment Polarization in Spain along the Cycle 1997-2012
}

\author{
Brindusa Anghel \\ FEDEA \\ Sara De la Rica \\ UPVIEHU, FEDEA and IZA
}

Aitor Lacuesta

Bank of Spain

\section{Discussion Paper No. 7816 \\ December 2013}

\author{
IZA \\ P.O. Box 7240 \\ 53072 Bonn \\ Germany \\ Phone: +49-228-3894-0 \\ Fax: +49-228-3894-180 \\ E-mail: iza@iza.org
}

Any opinions expressed here are those of the author(s) and not those of IZA. Research published in this series may include views on policy, but the institute itself takes no institutional policy positions. The IZA research network is committed to the IZA Guiding Principles of Research Integrity.

The Institute for the Study of Labor (IZA) in Bonn is a local and virtual international research center and a place of communication between science, politics and business. IZA is an independent nonprofit organization supported by Deutsche Post Foundation. The center is associated with the University of Bonn and offers a stimulating research environment through its international network, workshops and conferences, data service, project support, research visits and doctoral program. IZA engages in (i) original and internationally competitive research in all fields of labor economics, (ii) development of policy concepts, and (iii) dissemination of research results and concepts to the interested public.

IZA Discussion Papers often represent preliminary work and are circulated to encourage discussion. Citation of such a paper should account for its provisional character. A revised version may be available directly from the author. 
IZA Discussion Paper No. 7816

December 2013

\begin{abstract}
Employment Polarization in Spain along the Cycle 1997-2012 ${ }^{1}$

This article analyzes changes in the occupational employment share in Spain for the period 1997-2012 and the way particular sociodemographic adapt to those changes. There seems to be clear evidence of employment polarization between 1997 and 2012 that accelerates over the recession. Changes in the composition of the labour supply cannot explain the increase in the share of occupations at the low end of the wage distribution. Sector reallocation might have partially contributed to explain the polarization process in Spain during the years of expansion (1997-2007) but it is a minor factor during the recession. The polarization of occupations within sectors observed especially during the recession appear to be related to a decline in routine tasks which is compensated by an increase in occupations with non-routine service contents, which are found both in the low and high end of the wage distribution. Instead, jobs intensive in abstract contents do not appear to increase their share in total employment during these 15 years. The paper finds that this process has affected males more strongly than females because of their higher concentration in occupations more intensive in routine tasks. Among males, for workers under 30 years we find a decrease in the share of occupations with more routine tasks which turns into increases in others with more abstract content and particularly with more non-routine service content. Instead, male workers over 30 years seem to remain in declining occupations to a greater extent. Females of different ages are not affected by the abovementioned changes.
\end{abstract}

JEL Classification: E24, J24, J62, O33

Keywords: employment polarization, job tasks, routinization, business cycle

Corresponding author:

Sara De la Rica

Universidad del País Vasco

Facultad de Ciencias Económicas y Empresariales

Avenida Lehendakari Aguirre, 83

48015 Bilbao

Spain

E-mail: sara.delarica@ehu.es

\footnotetext{
${ }^{1}$ Authors gratefully acknowledge the support from the Ministry of Science and Technology from grants ECO2012-31985 and ECO2012-35820.
} 


\section{INTRODUCTION}

Structural unemployment depends on a broad set of factors among which there are some institutional considerations which have to do with labour market regulation, product market regulation and the mismatch between occupations demanded by the market and the ability of different skill group to match to them. This article analyzes the evolution of occupations in Spain for the period 1997-2012 identifying the structural part of this change. Moreover, it tests several hypotheses regarding the underlying factors of this structural change and the way particular sociodemographic groups adapt to it.

This question is relevant because one might want to use the observed changes in occupations over time to shed some light on the evolution of the demand for labour in the near future. However it is not clear at first sight to what extent those changes arise as a result of structural variation in the demand for labour or as a result of other forces. On the one hand, one must have into account that the Spanish labour force has undergone a notable structural change over the last cycle. Indeed, there has been a substantial increase in the schooling attainment of the population, in female participation and in the supply of low-skilled immigrants which has affected the supply skill composition in the economy. On the other hand, the employment share of the Construction Sector changed enormously along the cycle. Total employment in that sector increased around 5pp between 1994 and 2007 (from $8.7 \%$ to 13\%) and decreased by 7pp from 2007 onwards (reaching $6 \%$ of total employment by the first term of 2013 - a level more in accordance with the share of this sector in other European economies). Since the beginning of the actual recession and as a consequence of the construction bust, this sector contributed to almost half of the 3.8 million jobs destroyed, and it is certainly not expected that in the future it will recover the same level of activity as in the recent past. The paper will explore these issues in detail.

Recent evidence for a variety of countries has found a neat decline in the share of middle wage occupations which has been named polarization process. Indeed, some authors, such as Autor and Dorn (2012) find that this process has accelerated during the great recession. This reallocation of workers has been mainly observed within different industries and this has led many scholars to relate this phenomenon to a change in technology motivated by a decrease in the price of capital goods. Indeed, Autor et al (2003) and Goos et al (2009) relate the abovementioned polarization process to a decrease in the demand for occupations performing routine job contents or tasks that workers in the middle-wage occupations perform and which can be easily mechanized. On the other hand, 
it has also been documented that occupations which perform jobs that are more difficult to be substituted by technology such as abstract qualified occupations or unqualified jobs which require interpersonal skills are rising in relative employment terms. This means that workers previously performing routine tasks have been reallocated to jobs requiring either more abstract or more interpersonal service job contents or tasks.

There is a growing literature that finds that the allocation of skills into tasks might play an important role in explaining the difference in growth between the USA and Europe (Wasmer (2004)), the higher unemployment rate in Europe than in the USA (Ljungqvist and Sargent (1998)), the recent growth in wage inequality (Gavilán (2012), Autor et al (2003)) and jobless recoveries (Jamovich and Siu (2012)). Although Goos et al (2009) provide evidence of polarization for many European Countries, including Spain, this paper is the first one to address, in detail, the polarization hypothesis for Spain at different moments of the business cycle as well as its different impact on different sociodemographic groups of workers.

To this end the paper analyzes labour market changes over the last complete cycle (expansion and recession) to provide evidence of structural changes of the Spanish economy which might shape the way forward for its labour market. Indeed, since 1994, Spain had 13 years of economic growth and 5 years of recession. By comparing changes from the starting to the end point of a whole economic cycle we can distinguish structural movements from more cyclical ones. The paper focuses on labour market changes over the period 1997-2012 (ten years of expansion and five years of recession) instead of 1994-2012, which would delimit better the whole business cycle, because it is only since 1997 that we have access to 3-digit level data on occupations in our database, which is highly recommended in order to perform the matching of tasks to occupations. As a consequence we lose 3 years of expansion but that period is fairly similar to the period 1997-2012 in terms of labour force and employment composition.

Section 2 describes the important changes in the occupational distribution which Spain has gone through during these years. Whereas in the upper part of the wage distribution the share of managers, professionals and technicians has increased, in the lower part the share of retail sales and services occupations and low-skilled occupations related to the service sector has also increased. Instead, those jobs related to construction, agriculture or industry, regardless of their qualifications, have declined in terms of relative employment. Interestingly, the increases even in the high end of the wage distribution are related to service tasks more than to abstract ones. All these changes over the cycle are 
documented in the second section of the paper.

Section 3 is devoted to confirm empirically that Spain also went through a polarization process over the 15 year interval. Potential changes in this process between the expansion and the recession period are accounted for. In addition, the section explores different hypothesis behind the polarization process such as changes in the labour supply, changes in the sectoral structure and changes in technology within sectors. It is found that neither of the first two hypothesis can explain the whole polarization process, whereas the latter one seem to fit the process better. To test for the latter, we distinguish between the already mentioned "routine tasks" from "abstract tasks" (job contents which require active learning, management of personal resources, deductive reasoning, speech clarity, or complex problem solving) and "Non-Routine Service tasks"(which entail activities that require caring for others, establishing and maintaining interpersonal relationships, selling and influencing others and active listening). In the United States, polarization has been driven by a growth in abstract tasks - usually at the upper part of the wage distribution, and low-skilled services - usually at the lower end of the wage distribution, coupled with a decrease in occupations intensive in routine tasks which lie around mid-wage distribution. However, this pattern might not be extrapolated to other countries so we look at the connection between polarization process and changes in the occupational distributional driven by changes in the tasks performed by workers in Spain.

Finally, section 4 explores how changes in the demand for tasks over time pose different effects on different sociodemographic groups. Males and females at different stages of their life cycle are somehow segregated into different types of occupations and their ability to reallocate might differ because of their different capacity to readapt their accumulated human capital over time. Indeed, for the US, Autor and Dorn (2009) found that those in occupations more related to routine jobs have aged in the US, whereas workers in those more related to abstract and service jobs have become younger.

\section{CHANGES IN THE DISTRIBUTION OF EMPLOYMENT}

During the last 15 years, employment growth in the private sector has been heterogeneously distributed among occupations. Figure 1 presents changes in the employment shares of seven major occupational groups for the private sector (including self-employed). Occupations are ranked according to average 1995 wages, from highest to 
lowest. The figure reveals that between 1997 and 2012 there were three broad occupational groups which expanded their share in private sector employment. This are, according to the expansion magnitude, Managers, professionals and technicians, whose expansion reached 7.8 percentage points (henceforth pp); retail sales and service occupations, whose employment share increased in $3.91 \mathrm{pp}$ and finally, Low-skilled service occupations, with an almost negligible increase of $0.07 \mathrm{pp}$. The rest of the occupations declined in terms of relative employment. The occupational group which declined most is Production and Craft occupations 5,9pp; next, qualified workers in agriculture, which experimented a decrease of $3,7 \mathrm{pp}$, followed by machine operators and assemblers, with a decrease in 2,1pp. Finally, clerical and civil servants declined very slightly, $0.09 \mathrm{pp}$.

Notice that the expanding occupations are precisely those whose contents have much to do with either abstract or service tasks. Indeed the latter type of tasks appears to be much related with the increase in the share of expanding occupations. More than half of the increase in managers, professionals and technicians is associated with increases in the share of administrative and business associate professionals; physicists, chemists and engineer professionals and technicians; and salespersons and restaurant services workers which are managers on their own business. The big increase in retail sales and service occupations is associated with an increase in personal services and the increase in low skilled services is associated with an increase in domestic service occupations. Rather, the declining occupations seem to be much more associated with routine tasks. This will be further explored in section 3.

\section{[Insert Figure 1]}

It is also remarkable that expanding and declining occupations in the overall period remain as such when only the expansionary period (1997-2007) is taken into account. This provides an idea of the structural character of the changes in the employment composition across occupations in the Spanish economy regardless the sizable housing boom that the Spanish economy experimented during the expansionary period. From the comparison between the whole period and only the expansionary one, it looks like during the recession years (2007-2012) occupations related to managers, professionals and technicians are expanding much more than those related to non-qualified services. Indeed there is an important increase in the share of service sector managers between 2007 and 2012.

Given that gender segregation across occupations is high in Spain, it is interesting to represent changes in the structure of employment by occupation separately for men and 
women. Again this distinction might shed light on the structural character of the occupational changes since female were not as much affected by the housing boom and bust as males. Table 1 provides a static picture of the gender segregation of employment at 1997, the starting period of analysis. The evidence of the occupational segregation by gender is really high - males are much more concentrated in occupations related to machine operators, assemblers, craft and production whereas female jobs are basically associated with services of different types. The second interesting feature is that by 1997 males were overrepresented in declining occupations with respect to females.

[Insert Table 1]

Figures 2 and 3 represent the change in the distribution of occupations by gender over the whole 15-year period, as well as only for the expansionary period. As for males, Figure 2 reveals that over the 15 year interval the share of male employment increases to a greater extent in occupations related to Managerial, Technical and Professional jobs; also, although to a lesser extent in those related to sale and service occupations and finally, the increase is almost negligible in occupations related to machine operators and assemblers. On the contrary, male occupational shares decline sizably in production and craft (occupations related to the construction sector), qualified occupations in agriculture; and to a lesser extent in clerical and civil servant jobs and low skilled service workers (also related to the construction sector). If we focus only on the expansionary period, the most remarkable difference concerns the share of males working in occupations related to construction (production and craft and low skilled primarily). Contrary to the overall period, where the share of those two major occupation groups decreased, during the expansion, they increased strongly. Changes in the share of employment across the other occupations do not differ much between the two year intervals.

\section{[nsert Figure 2]}

With regards to women, changes observed for the overall period and for the expansionary period are very much the same with important increases in occupations related to Managerial, Professional and Technical jobs and retail sales. This is very much related with the enormous entrance of women into employment from inactivity during the recession as a result of the "added worker" effect. Many of these women are directed into jobs related to sales and services either as managers or as employees. With regards of other 
occupations, the share of female employment decreases in Manual Occupations, such as Production and craft and Machine Operators and Assemblers and increases slightly in low service occupations.

\section{[Insert Figure 3]}

To summarize, for both males and females and for the overall 15 year period, we observe increasing shares of employment in Managerial, Technical and Professional and retail sales and services occupations. On the other hand, we observe decreasing shares in Manual Occupations. In the following two sections we analyze with a higher degree of disaggregation whether the abovementioned changes in occupations could be understood in a polarization framework. We also analyze different hypothesis behind this process at different moments of the cycle and how different sociodemographic groups adapt to those changes.

\section{POLARIZATION AND THE OBSERVED CHANGES IN EMPLOYMENT SHARES}

\subsection{Is there evidence of Employment Polarization in Spain?}

Following Goos and Manning (2007) and Autor, Katz and Kearney (2006) we present some figures relating changes in the share of employment with the ranking of occupations in terms of average wages in Spain. We do so first for the entire period: $1997-$ 2012 and only for expansionary period - 1997-2007.

Figure 4 depicts changes in the occupational share of employment following the National Classification of Occupations (1994 - CNO-94) at 2-digit level. Occupations are ranked according to average wages at the beginning of the period. The ranking of wages is obtained from the 1995 Wage Structure Survey (Encuesta de Estructura Salarial (EES)), which is the nearest one to 1997, our initial period. ${ }^{2}$ Unfortunately, this evidence must be presented at 2-digit level occupational disaggregation and not at a higher one given that this

\footnotetext{
2 When considering the whole cycle (between 1994 and 2012), the increase in aggregate unemployment is lower. During those years the decrease in inactive population (6.9pp) was mainly absorbed by increases in employment (5.1pp) and unemployment as a share of total population only grew by $1.8 \mathrm{pp}$. However, its concentration on particular sociodemographic groups is the same as in the period 1997-2012. .
} 
is the maximum occupation disaggregation that is available from the different EES waves. We present changes in the share for the whole 15-year interval as well as only for the 19972007 expansionary period.

\section{[Insert Figure 4]}

There seems to be clear evidence of polarization, both for the expansionary and for the overall 15-year interval. Nevertheless, the expansionary period presents a somewhat different pattern of polarization than the whole 15 year period. In particular, during the first 11 years and coinciding with the expansionary period, low-paying occupations expanded their employment shares relative to average-paying occupations but also with respect to high-paying occupations. These patterns are consistent with the occupational changes described in the previous section. During the expansionary period, high-paid jobs such as professionals and managers increased their share slightly, but the increase in the share was strongest for the lowest-paid occupations, basically those related to low-skilled services. At least partially this might reflect the effect of the housing boom in the demand for low skill jobs. Taking the whole 15 years period high-paid jobs such as high-skilled services related to trade and sales and professionals and managers expand at a slightly higher pace than low-paid occupations such as low-skilled services or clerical jobs. This is overwhelmingly related to the increase in the share of managers of small businesses related to hotel, restaurants, retail and the service sector in general. Indeed, the increase in low skilled service workers is marginal probably due to the effect of the housing bust on low skilled services. The group of Retail sale and service occupations is the only one whose share increases among those occupations which lay at the low end of the wage distribution. Rather, the increase is much stronger at the upper end.

\subsection{Alternative explanations of the observed job polarization}

Is job polarization explained by changes in labour supply?

One potential explanation for the observed job polarization is that it is driven by changes in the composition of the labour supply. The substantial increase in the schooling attainment of the population, the increase in female participation and the increase in the labour supply of low-skilled immigrants may have shaped the supply of skills, increasing it particularly at both ends of the wage distribution and eventually driving a polarization process over the business cycle. Additionally, we know that over the crisis, highly educated 
workers have performed better than low skilled workers due among other things to the different incidence of temporary contracts in each of the groups. This factor might have biased the polarization process to the high end of the wage distribution during the recession.

Changes in the labour market activity during this 15 year interval are impressive. To give some features, the number of active workers increased by 5.8 million - an average annual increase of $1.1 \%$ - and the number of employed workers by 3.9 million - an average annual increase of $2 \%$. Furthermore, and as it has been documented by other studies (Izquierdo and Lacuesta (2012), Carrasco et al (2012)) those important employment changes have been unevenly distributed across particular groups of the population.

To test whether the observed changes in the labour composition may explain the observed job polarization we split the working population into 22 cells (gender (2 groups), educational attainment (3 groups), age groups for natives (3 groups), and 4 groups of immigrants depending on their gender and whether they belong to OECD countries or not). We construct counterfactuals of the distribution of occupations (at 2 digit level) in 2007 and 2012 keeping constant the 1997 structure of occupations within each cell and changing the relative weight of each cell.

Figure $5 \mathrm{a}$ and $5 \mathrm{~b}$ show that changes in the composition of the labour force would have increased the share of occupations placed at the upper end of the wage distribution instead of the polarization process described above. During the recession, compositional changes, if anything, might have contributed even more to the expansion of occupations at the upper part of the wage distribution. Therefore supply side changes cannot explain the increase in the share of occupations at the low end of the wage distribution and hence we require additional hypothesis to explain the observed polarization process.

\section{Is Job Polarization explained by changes in the sectoral structure?}

The Spanish economy has undergone a notable structural change over the last cycle. Indeed, the incidence of the Construction Sector in total employment increased around 5pp between 1994 and 2007 (from 8.7\% to 13\%) and decreased by 7pp from 2007 onwards (reaching $6 \%$ of total employment by 2013-Q1, a level more in accordance with the relative incidence of this sector in other European economies). Since the beginning of the actual recession and as a consequence of the construction bust, this sector contributed to almost half of the destruction of 3.8 million jobs. Therefore, it is likely that sector reallocation during the expansion affected the demand of certain occupations and hence 
change their share in total employment. To test for this, we can decompose observed changes in occupation shares in those which could be explained by changes in the sectoral structure of the Spanish economy (changes between sectors) from those changes which occurred within each of the sectors. Table 2 presents a shift share analysis for broader occupation groups ranked by average wages (as in Goos and Manning (2009)). Employment share changes across sectors can be attributed to demand changes whereas those within sectors should be more as a result of technology changes. For each of the two periods span, the first column shows the change (in pp) in the share of each occupational group. The second column reflects changes between industries and the third one changes within industries. When we consider the whole 15 -year interval, changes within industries are the most important ones behind the observed changes in the distribution of occupations. Changes within sectors expanded the employment share of low-paying occupations and high-paying occupations relative to average-paying occupations. The reallocation of workers from craft and production occupations towards Managers, Professionals and Technicians and sales and retail is crucial. On the other hand, during the expansionary period, changes between industries dominate at both ends of the wage distribution. By broader occupational groups, those changes across sectors during the expansionary period expanded the employment share of low-paying occupations and highpaying occupations relative to average-paying occupations. Changes within sectors during this period point towards the same direction of the abovementioned changes between sectors but their importance is minor.

Overall, as opposed to evidence from other countries (Goos and Manning (2006)) it appears that changes across sectors, potentially due to the housing boom, might have partially contributed to explain the polarization process in Spain especially during the period of expansion (1997-2007). Nevertheless, when considering a whole cycle (19972012) sector reallocation is less important in explaining the polarization process in Spain. We need an alternative hypothesis that could explain a polarization process from the point of view of technological changes within industries especially for the crisis.

\section{Is Job Polarization explained by the Routinization process?}

Levy and Murnane (2003) and more recently Acemouglu and Autor (2011) generalizes the so-called canonical model for the labour market. Such model includes twoskill groups of workers (high and low) who work in (imperfectly substitutable) occupations. Technology takes a factor-augmenting form, and thus may complement either high or low 
skill workers. Skill biased technical change is captured by changes in the factor-augmenting technology. The canonical model has proved to be conceptually tractable and empirically quite successful. However, it does not include a meaningful role for "tasks", or more precisely, imposes a one-to-one mapping between skills and tasks.

Acemoglou and Autor (2011) distinguish very clearly the concept of task from that of skill. The latter is a worker's endowment of capabilities to perform different tasks, whereas a unit of task is a unit of work activity which produces output. This distinction is essential if we believe that workers of a given skill level can perform different tasks and furthermore, can change the combination of tasks they perform in response to changes in labour market conditions and technology. These authors develop a task assignment model where it is assumed that there is a continuum of tasks which together produce a final good.

Intuitively, each worker is endowed with either one of the following three types of skills - high, medium and low. Differences in comparative advantage among workers to perform different tasks together with the market prices of different tasks as well as wages for different skills, lead workers to endogenously decide the optimal allocation of skills to tasks. And in equilibrium, Acemoglou and Autor (2011) formally derive that the least complex set of tasks are supplied by the low skilled workers, the intermediate set of tasks by the medium skilled workers and finally the most complex tasks will be provided by the high skilled workers.

One of the most attractive features of this model is that it can be used to investigate the implications of technological changes on workers displacement from previously performed tasks. In particular, routine task, which are mostly performed by medium skilled workers, are those most subject to machine displacement, and therefore task-replacing technological change can directly reduces wages of the medium skilled group independent of changes in total output. As these workers lose comparative advantage in routineintensive activities, they must be reallocated either to the higher and the lowest tails of the occupational distribution, leading to employment polarization.

To test this theory, Peri and Sparber (2009), Goos et al (2010) and Amuedo and De la Rica (2011), match occupations with particular job contents or tasks. Each occupation requires a fraction of three types of job contents: Abstract tasks, Routine tasks and nonRoutine Service tasks. See appendix for details about the data used in this section and about matching tasks and occupations. Table 3 presents the abovementioned job contents for the 7 broad occupational groups used in Section 2, and as one might expect, high- 
skilled occupations, such as managers, professionals have the highest abstract and the lowest routine content. Rather, occupations such as Production and Craft or Machine Operators display the highest routine and the lowest service and abstract content.

\section{[nsert Table 3]}

In order to check whether there is correlation between changes in the employment shares by occupations and task intensities, we regress (separately) changes in the share of employment by occupation (3-digit ISCO88 occupations) on the following measures of job contents: (i) abstract intensity, (ii) service intensity and (iii) routine intensity. In addition, following Goos et al (2010, tables 6A, 6B and 7) and Autor and Dorn (2012), we also use a routinization index in a separate regression, which combines the previous three measures to create an index of routine task-intensity by occupation, which is defined as follows:

\section{Routinization Index $=\log ($ Routine Intensity $)-\log ($ Abstract Intensity $)-\log ($ Service Intensity $)$.}

This index increases with the rise of routine intensity and declines with the rise of abstract and service intensity.

Table 4 presents the results of these estimations. The dependent variable is the change in the share of employment for each 3-digit ISCO88 occupation. We perform the estimations for the whole 15-year interval (1997-2012) and for the expansionary period (1997-2007). In the table, each coefficient is the result of a different OLS regression.

[nsert Table 4]

Results suggest that when using the Routinization Index as the regressor there seems to be a negative impact of the index on the change in the share of employment, only significant for the recession period. When separating out the different task intensities, there is no significant correlation between the change in the share of employment and the "Abstract Intensity" of occupations. This is true when considering the whole 15-year interval jointly and for separate regressions in each period. On the other hand, "Routine Intensity" of occupations exhibits a clearly negative correlation with the change in the share of employment in the recession period. Finally, "Non-routine Service Intensity" of occupations is positively and significantly correlated with the change in the share of employment. As before, the impact is particularly strong in the recession period.

In this regard, the evidence above shows that during the expansion period there was 
polarization but the routinization theory does not hold. This is consistent with results in the previous section that showed that polarization mainly came via a reallocation of sectors. Indeed it is likely that the big expansion of the Spanish labour force coupled with the construction boom delayed the rapid mechanization of certain routine occupations that occurred in other countries in the pre-crisis period. During those years, there was a notable increase in the share of low-skilled service occupations, such as personal services and workers in restaurants and hotels, but also in the share of low-skilled routine tasks such as cleaners of buildings. On the other hand, middle-skilled occupations with higher routine content, high skilled service occupations (such as professional services) and occupations requiring abstract tasks (support in the financial sector and the administration) also increased their share although at a slower pace. During the recession, however, it appears that there is a clear decrease in the share of those routine occupations that could be easily mechanized (especially related to the construction bust and the industry decline). This is compensated by non-routine services that move upward both low-paid (cleaners and personal services), and high-paid occupations (managers and professional services related to the service sectors as observed in section 2). Instead, abstract tasks do not appear to increase their share during these 15 years.

\section{Robustness check}

Our approach to test for the routinization hypothesis has consisted on assigning tasks to occupations using job task descriptions. In particular, we have used the Occupational Information Network (O*NET), which is the successor of the Dictionary of Occupational Titles (DOT). Both of them offer sources for job descriptors in empirical studies on tasks. One of the difficulties which both types of job descriptors present is that job content measures are often vague and repetitive. Furthermore, it is not always clear which job content measures should be assigned to abstract, routine and service intensive tasks. We have followed exactly the same approach as Goos et al (2010) in assigning job contents to tasks. However, there may be some arbitrary decisions with regards to which job contents are abstract, service and in particular routine intensive. In particular, with respect to the latter, Goos et al (2010) consider routine intensive job contents such as Operation Monitoring and Operation and Control, but also other job contents such as arm-hand steadiness, manual dexterity, finger dexterity and strength. While the first two ones are clearly related to routine tasks as they relate to clerical and production work, some of the others may be more related to manual but not routine ones. Indeed, some recent 
authors, such as Autor and Dorn (2013) using the DOT descriptors use only the two first ones to describe routine intensive tasks, i.e., Operation Monitoring and Operation and Control.

In order to check whether our assignment of job contents to tasks might change the results previously found, we have used an alternative definition of routine intensive jobs only those whose content relate to Operation Monitoring and Operation and Control as Autor and Dorn (2013). The rest of job contents previously assigned as routine intensive by Goos et al (2012) have been left aside. Given that abstract, routine and service tasks are in relative terms, each of the measures have been redefined in base of this alternative routine task. Results, although not reported and available upon request, are qualitatively identical to the ones found in the previous section, which suggests that the definition of routine intensive tasks used in this paper is not driving the results.

\section{THE EFFECT OF POLARIZATION FOR PARTICULAR DEMOGRAPHIC GROUPS}

This section introduces the link developed by Autor and Dorn (2009) with regards to the implication of the routinization theory for the change in the distribution of employment by age. Routinization implies the displacement of occupations which are intensive in routine tasks to occupations more intensive in non-routine (service or abstract) job contents. This non-neutral occupational change may change the age composition of occupations if there are different incentives and/or abilities of workers to entry/exit from rising/declining occupations at different stages of their life cycle. In their paper, they find that older workers, regardless of their skills, moved from routine to non-routine low-skilled jobs, whereas the displacement of young workers from routine jobs increased the share of both low-skilled non-routine jobs and abstract high-skilled jobs.

In this fourth section, we look specifically at employed workers and analyze how their age structure changes in rising and declining occupations. To this end, we follow Autor and Dorn (2009) and estimate changes in the age composition of workers in each occupation for each of the year-intervals considered before on the three different job contents, as well as on the routinization index. We do so separately by gender.

However, before looking at changes in the age structure in declining and expanding 
occupations over time, the distribution of male and female across occupations by age at the initial period deserves some attention. As Table 1 indicates, by 1997 males were overrepresented in declining occupations with respect to females. The percentage of young females in managerial and service occupations (52\%) was in 1997 much higher than the corresponding percentage for males (29\%). Interestingly, although not reported, at a further occupational disaggregation - at 2-digit level, young males in managerial/technical/professional occupations are overwhelmingly concentrated in jobs such as chemistry/physics technicians, engineers or professionals in finance and trade, all of which are very intensive in abstract contents. On the contrary, their female counterparts are concentrated in occupations such as teaching professionals, health professionals and administrative associate professionals, which require more service intensive tasks. With respect to non-managerial/technical/professional jobs, young males are scattered along production occupations, low skilled occupations (especially industry and construction pawns), machine operators and to a lesser extent retail and sales. All these occupations use quite intensively routine tasks. However, young females in nonmanagerial/technical/professional occupations are distributed among clerical, retail and sales occupations and to a lesser extent into low skilled service occupations - in particular in personal services. All these occupations require primarily service rather than abstract or routine tasks.

Given this, if we think about the impact of polarization on the reallocation of males and females across job contents, we would expect a change in the distribution of tasks of young males as a consequence of the decrease in the demand for routine tasks and an increase of abstract and service tasks. Something similar would occur with older males given that they are overrepresented in routine occupations related to machine operators and production and craft. However, for male workers between 31 and 45 years old at 2012, cohort effects must be taken into account when interpreting the changes over time, as by 1997 these workers belonged to the youngest group. These cohort effects are not expected to be important when analyzing the group of male workers over 45 years old since the distribution of occupations in 1997 was similar to the one of middle age workers. With respect to female reallocation, we would not expect much change in task performance as a result of the polarization process since by 1997 females seemed to be very concentrated in occupations which did not require routine intensive tasks. These issues must be taken into account when interpreting the results. 
In order to account for the changes in the age composition, we use two different measures: the change in the mean age of each occupation and the change in the share of workers in each occupation (i) less than 30 years old, (ii) between 31 and 45 years old, and (iii) more than 45 years old.

According to the regressions where average age is the dependent variable (Table 5), we observe that workers in occupations with more abstract content are becoming younger, as average age decreases. This is particularly so in the expansionary period. For the recession period, given the mass layoffs of younger workers with temporary contracts, this phenomenon is not observed. However, the recession does not overcome the effect of the expansionary periods and, taking into account the whole cycle (1997-2012), workers in abstract occupations also become younger. By gender, it appears that only for males we do observe the decrease in average age in occupations with more abstract content over the whole cycle. There is also a decrease in average age of females in abstract occupations in the expansionary period, but this is reversed in the recession. For the overall period, no significant change in average age is found for females.

In occupations with more routine content, we observe a slight aging of workers, as average age seems to increase. The effects by sub-periods are only marginally significant, but when the whole 15-year period is considered, we see a positive and stronger effect. When we disaggregate this by gender, we observe that if anything, the effect is driven by males, as we observed in occupations with higher abstract content.

\section{[Insert Table 5]}

In occupations with more non-routine service content, we observe a very similar feature to the one observed for occupations with abstract contents, but the effect seems to be smaller, namely, those workers in occupations with more service content are becoming younger. In this case, and differently from what happened with occupations with more abstract content, the effect is found to be significant in the recession period. As in the previous two cases, the effect is stronger for males. Indeed, for females the effect is not significant.

Regressions of the change in the share of workers by age provide more information on which age groups of workers are driving the previous results. Table 5 shows a process of rejuvenation motivated by an increase in the share of workers between 16 and 30 years old in occupations with more abstract and service contents. The former, which is especially intense, occurs during the expansion and the latter during the recession years. On the other 
hand, a clear aging effect is observed for occupations with more routine content. Again, there is no statistical effect for.

\section{[nsert Table 6]}

Tables 6 indicates that the share of middle-agers in routine tasks has increased substantially with the corresponding decrease in the share of occupations with both abstract and service content. This is consistent with the hypothesis that cohort effects are playing a role. This is not observed for females (indeed the point estimate corroborates a decrease in occupations of routine content).

Table 7 provides evidence for older workers. This group should not be as much affected by cohort effects. The evidence points towards a group of workers who are stuck in routine tasks. This could be the case because of high firing costs for those over 45 years old, as most of them hold indefinite contracts. Again females do not show any relevant effect. If any, there is a slight increase of female incidence in occupations which require more service intensive contents along the crisis. We must look at these results with caution. Further research is needed to disentangle properly cohort effects from the reallocation of particular group of workers. .

\section{[Insert Table 7]}

To summarize, the observed polarization process over the 15-year period under analysis seems to have reallocated young male workers from occupations with more routine tasks to others with more abstract and non-routine service content ${ }^{3}$. Female young workers who were already performing occupations with a high service content are not affected by this technological change. The fact that they are not working in abstract tasks is quite stunning and should be addressed carefully in further research. Instead, it looks like male workers above 30 years are the ones who have stayed in the declining occupations more, especially those above 45. It is likely that this is the case because of the high severance payments that they have acquired during his lifetime.

\footnotetext{
${ }^{3}$ We must not overcome the fact that young males have been hit by unemployment to a greater extent than their young female counterparts and than older males. Therefore, when we refer to reallocation of young males we restrict attention to employment shares, and to some extent ignore compositional changes due to exits from employment into unemployment.
} 


\section{CONCLUSIONS}

This article analyzes changes in the employment share of occupations in Spain for the period 1997-2012 and the way particular sociodemographic groups adapt to them. We analyze a whole cycle in order to find structural factors underlying such changes but we address the extent to which these occupational changes have differed during the expansion and the recession years.

On the first hand we address whether Spanish occupations experienced a process of polarization. That is, whether those occupations in the low and high end of the wage distribution expanded relative to the rest. We find clear evidence of polarization, both for the expansionary and for the recession period as well as for the whole 15-year interval. Nevertheless, there is a distinct pattern of polarization between 1997 and 2007 and the recession period. During the first 10 years and coinciding with the expansionary period, low-paying occupations expanded in employment terms relative to average-paying occupations but also with respect to high-paying occupations.

Next we test whether those changes follow from hypothesis such as changes in the composition of the labour supply or changes in sector allocation. We show that changes in the composition of the labour force would have increased the share of occupations placed at the upper end of the wage distribution instead of the observed polarization process. During the recession, compositional changes, if anything, might have contributed even more to the expansion of occupations at the upper part of the wage distribution. Therefore supply side changes cannot explain the increase in the share of occupations at the low end of the wage distribution. Regarding sector reallocation, we perform a shift share analysis of the changes to conclude that overall changes across sectors, potentially the housing boom, might have partially contributed to explain the polarization process in Spain especially during the period of expansion (1997-2007). Nevertheless, when considering a whole cycle (1997-2012) within sector changes are the major factor behind the observed occupational changes.

We then explore whether polarization arises as a result of a decrease in occupations which are intensive in routine contents. In this regard, we find that indeed the observed polarization is consistent with a decrease in occupations intensive in routine content and an increase in those intensive in non-routine services which are found both at the low and high end of the wage distribution. Instead, occupations with higher abstract tasks do not appear to have expanded during these 15 years. 
Needless to say, these changes in the employment composition are not homogeneous across different sociodemographic groups. The paper finds that the observed decrease in routine occupations over the 15 years under analysis seems to have affected males more strongly than females as a result of their higher concentration in occupations which are intensive in routine tasks. Indeed, for male workers the share of unemployed over the population has increased notably regardless of the age group. Young male workers decrease their share in occupations with more routine tasks and increase it in occupations with more abstract and in particular with more non-routine service content. Rather, male workers over 30 years tend to stay in the declining occupations. Females, given that they were not allocated to routine tasks during the expansionary period are not as much affected by those changes probably due to the fact that they were already more specialized on jobs with high service content.

\section{REFERENCES}

Amuedo Catalina and S. De la Rica (2011). "Complements or Substitutes: Task Specialization by Gender and Nativity in Spain". Labour Economics, 18:5; pp697-707

Autor, David and D. Dorn (2009) "This Job is "Getting Old": Measuring Changes in Job Opportunities using Occupational Age Structure”, American Economic Review: Papers \& Proceedings 99:2, 45-51

Autor, David; F. Levy and R. Murnane (2003) “The Skill Content of Recent Technological Change: An Empirical Investigation”, Quarterly Journal of Economics, 118:4, pp.12791333

Autor, David and D. Dorn (2012), "The Growth of Low Skill Service Jobs and the Polarization of the U.S. Labor Market" forthcoming American Economic Review

Autor, David; L. Katz and M. Kearney (2006) "The Polarization of the U.S. Labor Market”, American Economic Review, 96:2, pp.189-194.

Bonhomme, Stephanne and L. Hospido (2013) "Earnings Inequality in Spain: New Evidence using Tax Data", Applied Economics, 45:30, pp.4212-4225.

Carrasco, Raquel; J.F. Jimeno and C. Ortega (2012) "Accounting for Changes in the Spanish Wage Distribution: the Role of Employment Composition Effects” Banco de 
España Working papers 1120

Cullison, William (1979) “The Determinants of Labor Force Participation: an Empirical Analysis” Federal Reserve Bank of Richmond. Working paper 79:3

Duval, Romain; M. Eris and D. Furceri (2010) "Labour Force Hysteresis in Industrial Countries: Evidence and Causes”. Mimeo. OECD Economics Department

Goos, Maarten and A. Manning. (2007) "Lousy and Lovely Jobs: The Rising Polarization of Work in Britain" Review of Economics and Statistics 89:1.pp 118-133.

Goos, Maarten; A.Manning and A.Salomons (2009) "Job Polarization in Europe" American Economic Review Papers and Proceedings, 99:2; pp.58-63

Goos, Maarten; A. Manning and A.Salomons (2010) "Explaining Job Polarization in Europe: The Roles of Technology, Globalization and Institutions" CEP Discussion Paper No 1026, November.

Gavilán, Ángel (2012) 'Wage Inequality, Segregation by Skill and the Price of Capital in an Assignment Model”. European Economic Review; 56:1.pp:116-137

Izquierdo, Mario and A. Lacuesta (2012) "The contribution of changes in employment composition and relative returns to the evolution of wage inequality: the case of Spain" Journal of Population Economics 25:2;pp. 511-543.

Nir Jamovich and Henry E. Siu (2012) "The Trend is the Cycle: Job Polarization and Jobless Recoveries” NBER Working Paper 18334

Ljungqvist, Lars and T. Sargent (1998) “The European Unemployment Dilemma”, Journal of Political Economy, 106:3;pp.514-550

Montero (2011) "El Comportamiento de la Tasa de Actividad durante la Última Fase Recesiva", Boletín Económico del Banco de España Abril, pp.89-97

Ortega, Francesc and J. Polavieja (2012), “"'Labor-market Exposure as a Determinant of Attitudes toward Immigration.” Labour Economics 19 (2012), pages 298-311. DOI information: 10.1016/j.labeco.2012.02.004.

Peri, Giovanni and C.Sparber (2009) “Task Specialization, Immigration, and Wages", American Economic Journal.Applied Economics 1:3.pp135-169

Pijoan, Joan and V. Sánchez-Marcos (2010) "Spain is Different: Falling Trends of Inequality" Review of Economics Dynamics 13:1; pp.154-178

Ward-Warmedinger Melanie; K. Masuch; R. Gómez-Slavador; N.Leiner-Killinger; R.Strauch; J.Turunen; J. De Mulder; H.Sthal; D. Nicolitsas; P.Cipollone; A. Lacuesta; A.Stigblauer, K; Stovicek, A; Balleer, K; McQuinn; P. Montanaro; A. Rosolia; 
E.Viviano; C.Duarte (2008) "Labour Supply and Employment in the Euro Area Countries: Developments and Challenges" ECB Occasional Paper 87

Wasmer, Etienne (2004) "Interpreting Europe and U.S. Labor Market Differences: The Specificity of Human Capital Investments"; Quarterly Journal of Economics 117:1 


\section{APPENDIX 1: Occupations and Measures of Job Contents:}

To match occupations with particular job contents we rely on information on job task requirements assembled by Peri and Sparber (2009) for the US, Goos, Manning and Salomons (2010) for different European countries, and Amuedo and De la Rica (2011) for Spain, among others. The starting point is to merge data on job contents (or task requirements) based on the U.S. Department of Labor's ONet survey ${ }^{4}$ with Census occupation classifications to examine task specialization patterns of workers. ONet is a primary source of occupational information providing data on key attributes and characteristics of occupations. It replaces the Dictionary of Occupational Titles (DOT), which was used for earlier research, prominently by Autor, Levy and Murname (2003). ONet data is collected for 812 occupations based on the 2000 Standard Occupational Code (SOC).

Through the development of careful crosswalks with the International Standard Classification of Occupations from 1988 at 3-digits level (ISCO88), ONet data has been increasingly used by a large number of researchers and institutions outside the United States $^{5}$. We merge the ONet job skill data with the Spanish Labor Force Survey with occupations disaggregated at 3-digits level ${ }^{6}$. Like previous authors using the ONet dataset with European data ${ }^{7}$, we do so under the assumption that the occupations in the US and in Spain being examined herein are not that different with regards to the specified job contents.

ONet consists of around 100 variables related to the intensity of different job activities and abilities for each occupation. The original values range from 1 (very low intensity) to 5 (very high intensity). For comparability reasons, we use exactly the same variables as in Goos, Manning and Salomon (2010) to construct the job content measures we use for the analysis. Specifically, we make use of 96 of these variables and each of them is categorized into one of the following job contents: Abstract, Routine and non-Routine Service.

To give a broad idea of what type of content is included in each of the three measures, "Abstract Intensity" measures the extent to which each occupation entails

\footnotetext{
${ }^{4}$ For the rest of the section on polarization, we will use the 3-digit ISCO-88 classification.

${ }^{5}$ In general, statistical significance of the regressions of females is low compared to that of males, but the signs coincide.

${ }^{6}$ They use version 11.0 of the survey, available at: http://www.onetcenter.org/

7 The ONet rates the importance of 99 job characteristics, including employee skills and employee activities to which we refer to as task requirements or tasks in this paper- in each occupation in the Standard Occupation Classification (SOC). This information is continually updated by surveying a broad range of workers from each occupation in the US.
} 
activities such as: active learning, learning strategies, management of personal resources, management of material resources, deductive reasoning, speech clarity, complex problem solving, etc. "Routine Intensity" measures the extent to which each occupations entails activities such as: operation monitoring, operation and control, quality control analysis, arm-hand steadiness, manual and finger dexterity. Finally, "Non-Routine Service Intensity" measures the extent to which each occupation entails activities such as: assisting and caring for others, establishing and maintaining interpersonal relationships, selling and influencing others, active listening. The exact definition of each job content is detailed in Goos, Manning and Salomon (2010, Table C1 (pp: 73)).

In order to construct the final measure of intensity in each of the described job contents, we must realize that the standard deviation varies to a great extent depending on the skill under consideration. This problem is also detected and accounted for by Peri and Sparber (2009), who tackle it by transforming the ONet job skill data to reflect the relative importance of each skill among all US workers in 2000. Like them, we transform the original job content data to reflect the relative importance of each skill among all workers in Spain during the time period under examination.

As in Peri and Sparber (2009), the final measures of Abstract, Routine and NonRoutine Service Job Contents are the weighted averages of the intensity of the activities included under each of the three measures. ${ }^{8}$ In addition, given that our aim is to provide relative measures of intensity of abstract, routine and non-routine service job contents for each occupation, we normalize the intensity of each of these three job contents within occupations so that the sum of the intensities of the three of them is 1.

Table 2 displays the Abstract, Routine and Non-Routine Service Job Content values for each of the eight big occupational groups. This allows us to gauge the suitability of the ONet data in describing the distinct job content of the main Spanish occupational categories. As expected, high skill occupations, such as technical and professional occupations display a higher value of Abstract Content and a smaller value of Routine Content. The contrary is observed for low skill occupations, such as machine assemblers and low-qualified service occupations. With regards to the intensity of non-routine service jobs, higher values are observed for occupations at the two tails of the skill distribution.

\footnotetext{
8 See http://www.onetcenter.org/dl_files/paw/Products_at_Work.pdf for a summary of its many applications outside the US.
} 
Figure 1: Changes in the Share of Private Sector

Employment by Occupation

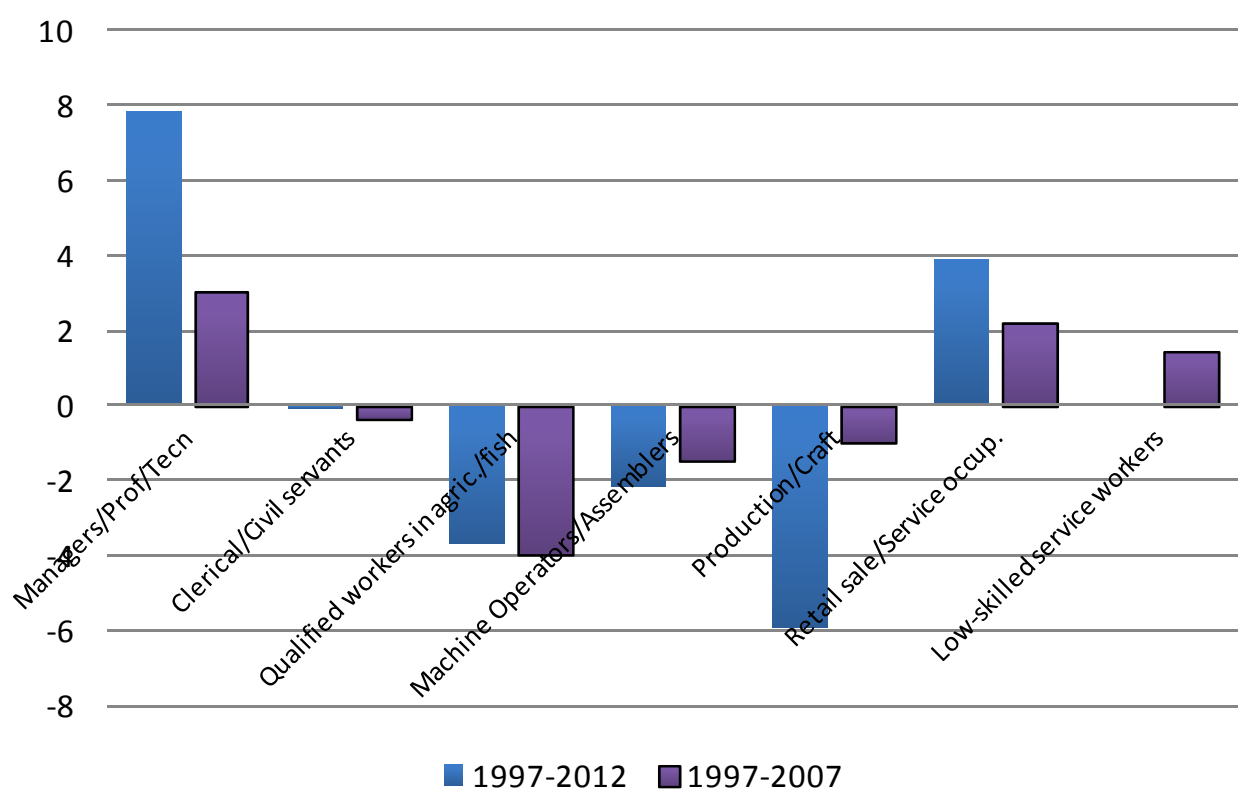

Figure 2: Changes in the Share of Private Sector Employment by Occupation - Males

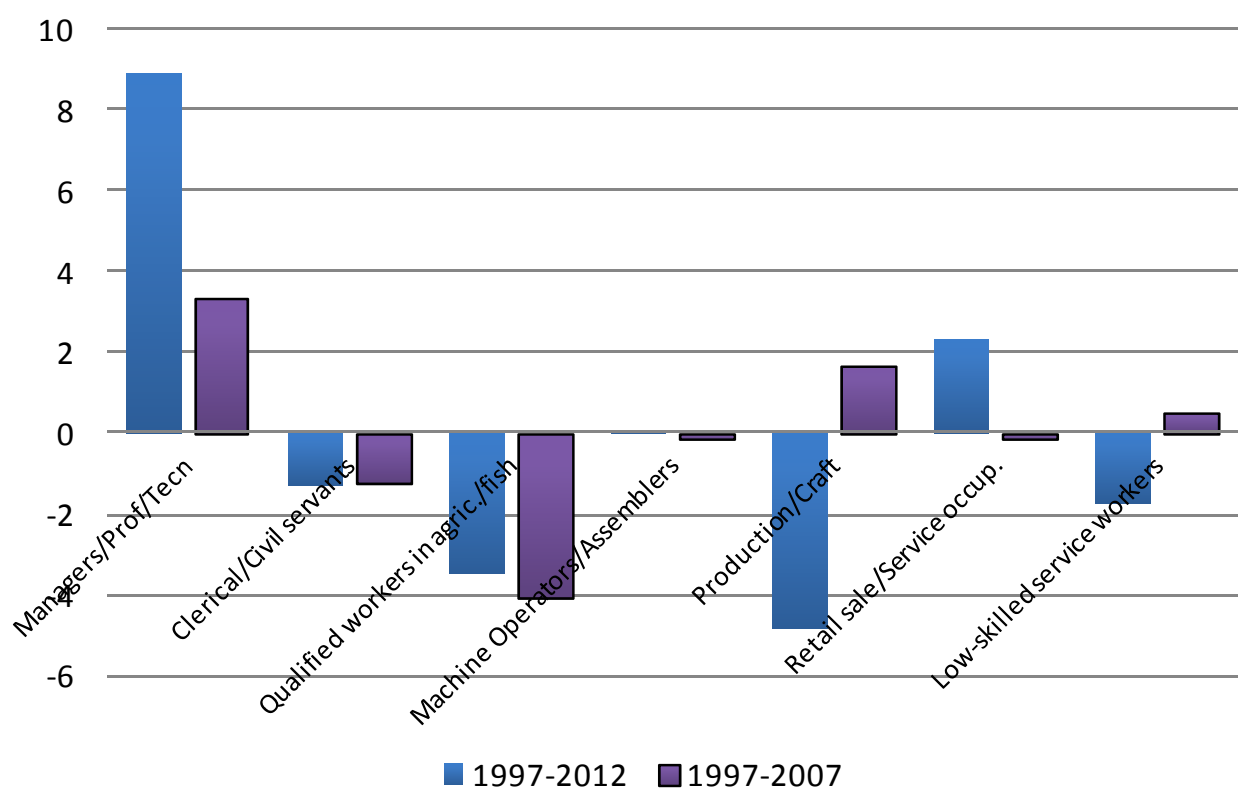


Figure 3: Changes in the Share of Private Sector Employment by Occupation - Females

8

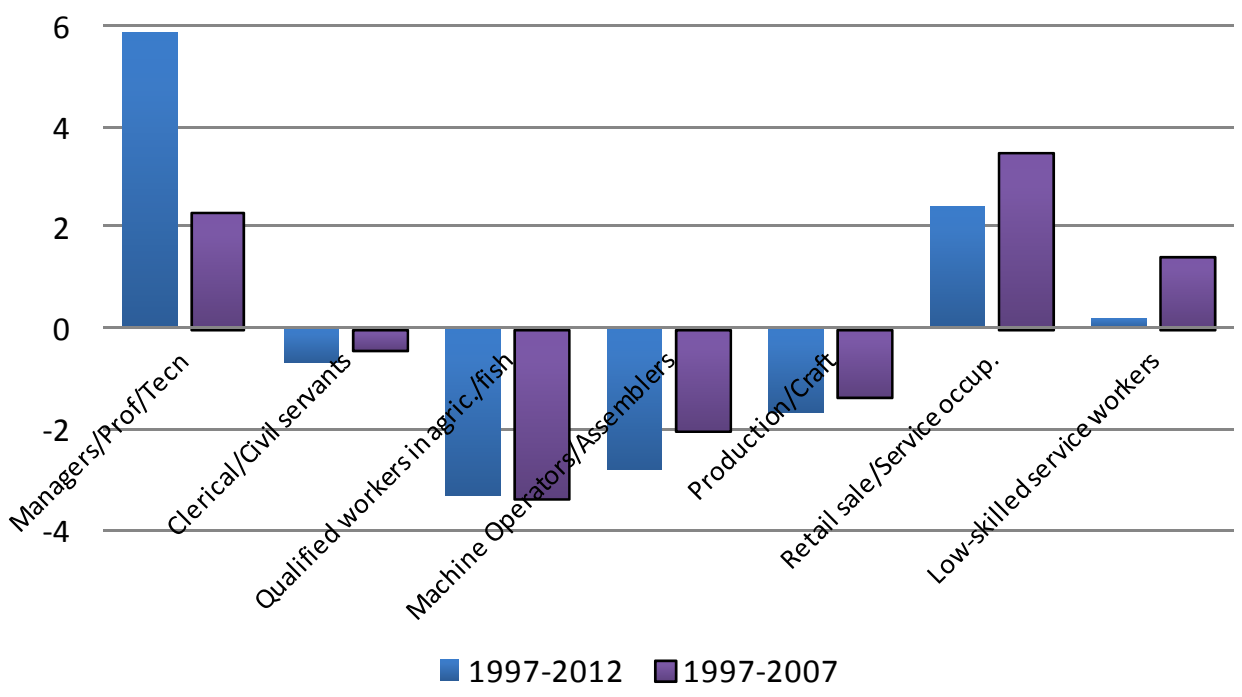

Figure 4: Smoothed change in employment shares by occupations

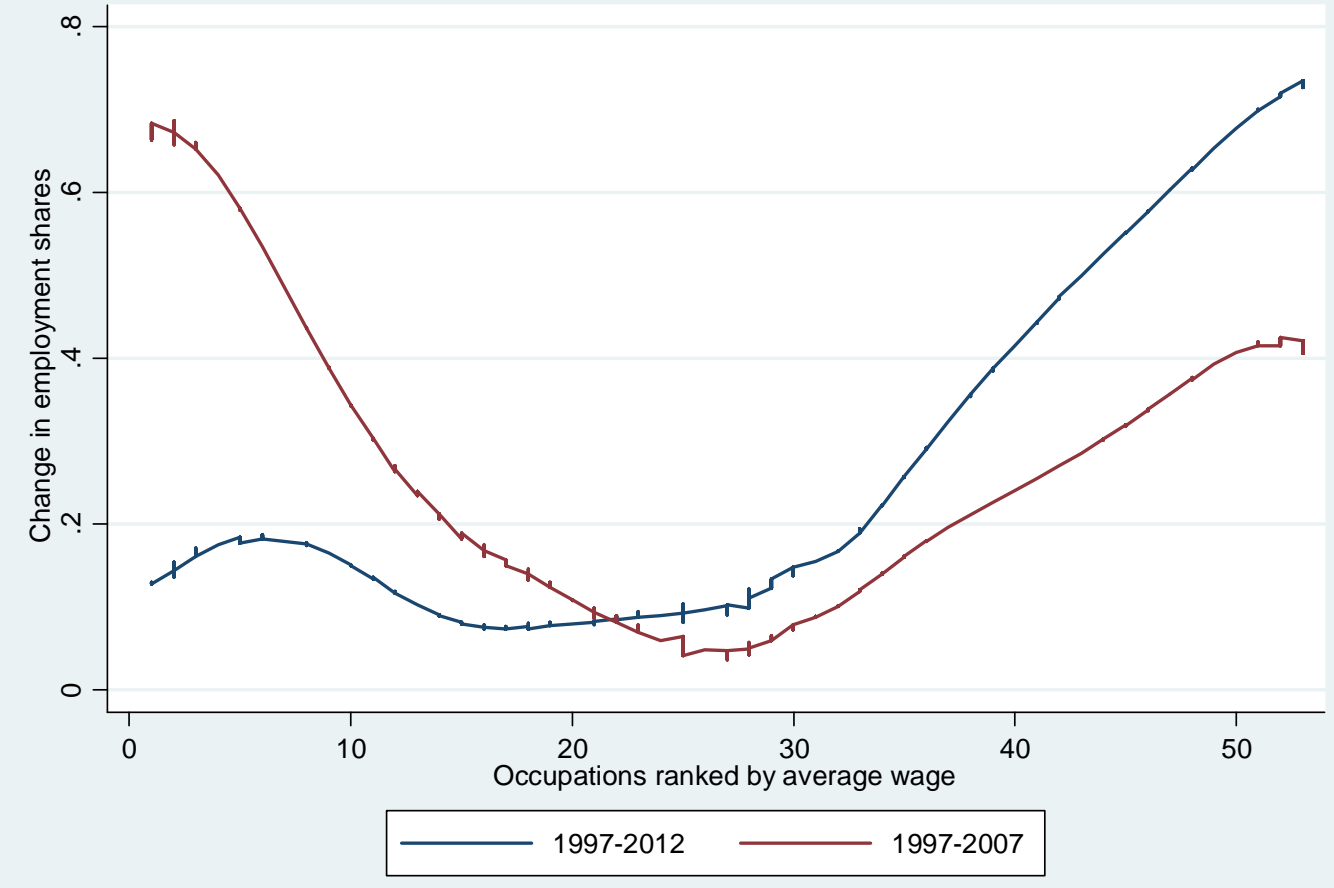


Figure 5a: Smoothed change in employment shares by occupations. 1997-2012

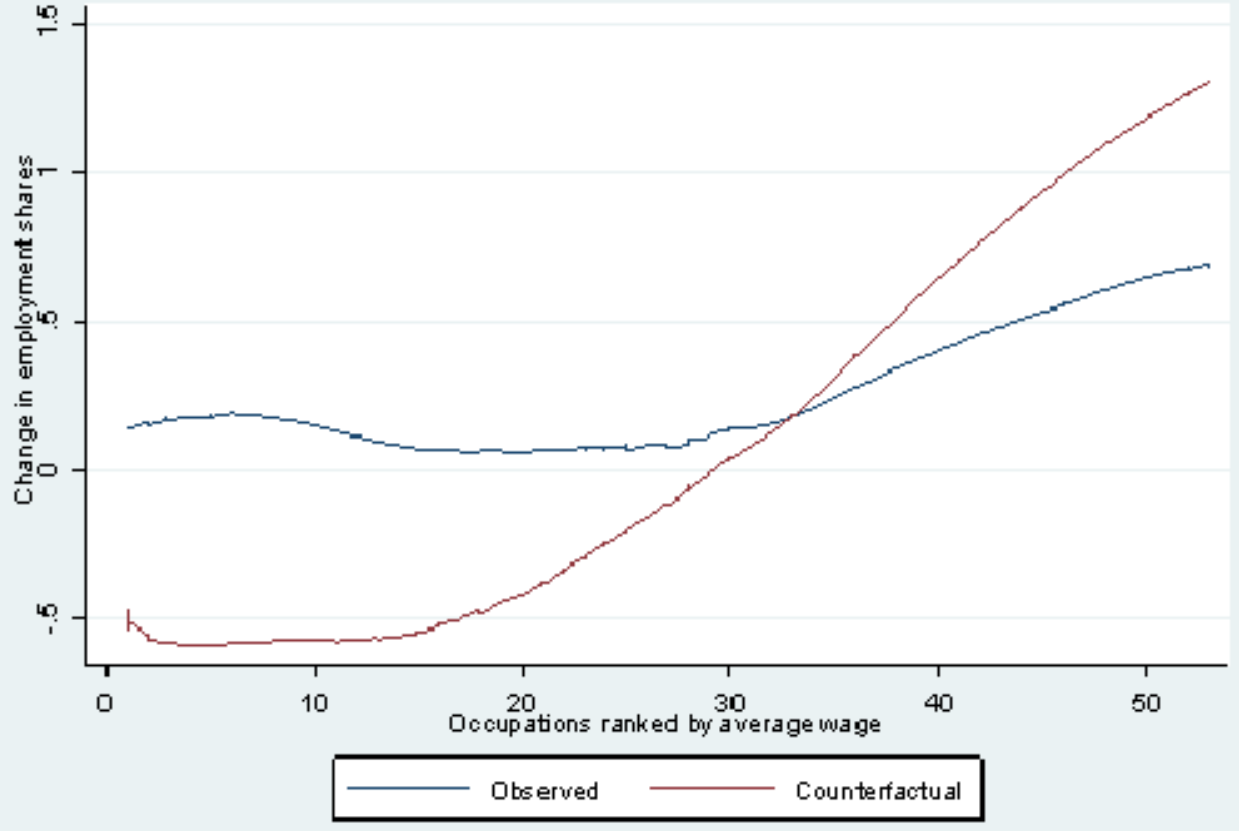

Figure 5b: Smoothed change in employment shares by occupations. 1997-2007

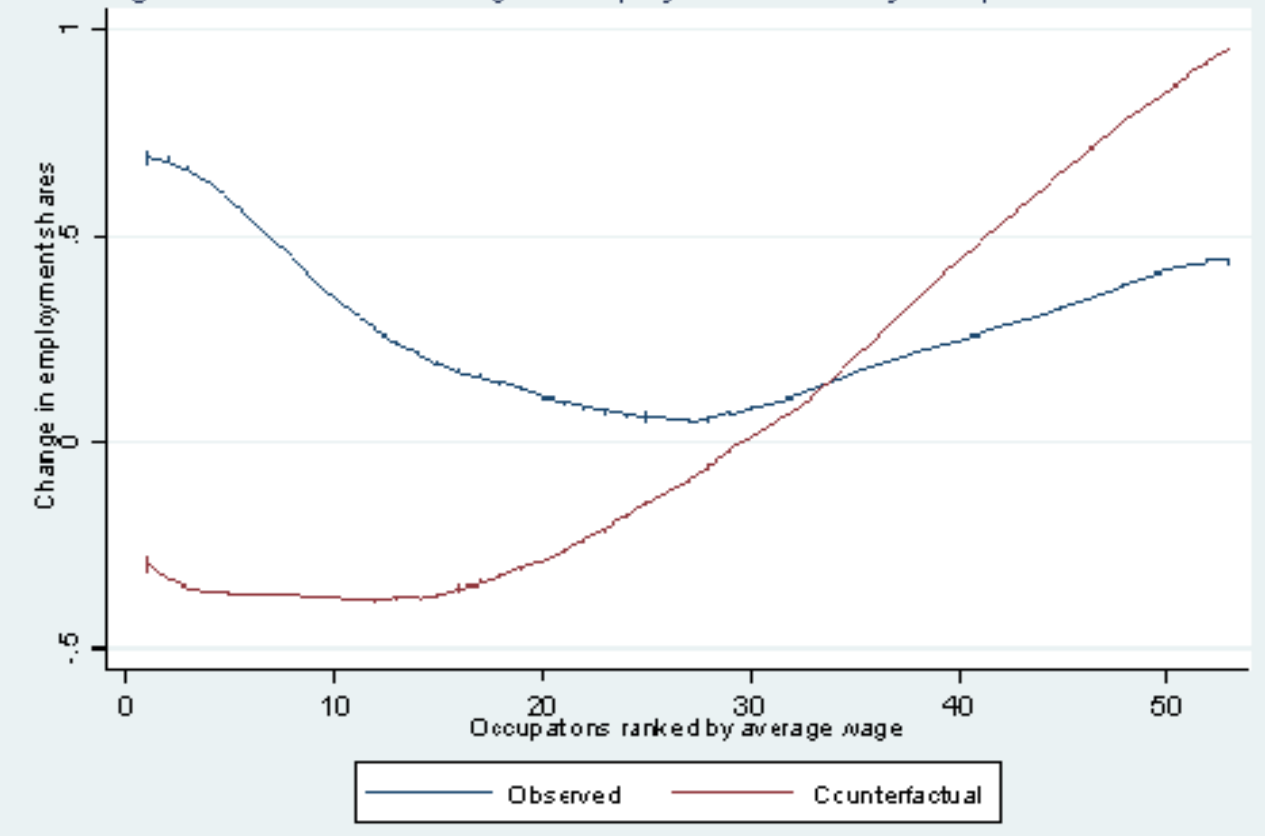


Table 1: Share of private sector employment by occupation. 1997

\begin{tabular}{|c|c|c|c|c|c|c|c|c|}
\hline \multirow{2}{*}{ Occupational groups } & \multirow{2}{*}{ Average wage } & \multirow{2}{*}{ Overall } & \multicolumn{2}{|c|}{$16-30$} & \multicolumn{2}{|c|}{$31-45$} & \multicolumn{2}{|c|}{$46-64$} \\
\hline & & & Males & Females & Males & Females & Males & Females \\
\hline Clerical/Civil servants & 13.895 & 9,09 & 6,4 & 20,47 & 6,77 & 14,28 & 5,36 & 6,88 \\
\hline Machine Operators/Assemblers & 13.418 & 11,8 & 13,91 & 6,03 & 15,37 & 6,08 & 14,98 & 4,22 \\
\hline Production/Craft & 12.945 & 19,64 & 26,84 & 4,06 & 27,68 & 4,13 & 26,98 & 4,26 \\
\hline Retail sale/Service occup. & 11.079 & 13,3 & 13,02 & 29,54 & 8,09 & 20,02 & 4,69 & 17,66 \\
\hline Low-skilled service workers & 9.049 & 14,76 & 19,36 & 16,23 & 8,2 & 22,3 & 9,15 & 26,51 \\
\hline
\end{tabular}

Source: Spanish Labour Force Survey (LFS) and Wage Structure Survey (WSS) 1995 
Table 2: Decomposition of the changes in the share of private sector employment by occupation

\begin{tabular}{|c|c|c|c|c|c|c|}
\hline & \multicolumn{3}{|c|}{$1997-2012$} & \multicolumn{3}{|c|}{$1997-2007$} \\
\hline & Change ocup & Within & Between & Change ocup & Within & Between \\
\hline Managers/Prof/Assoc & 7,43 & 6,21 & 1,22 & 2,82 & 1,01 & 1,81 \\
\hline Clerical/Civil servants & 0,06 & $-0,26$ & 0,32 & $-0,26$ & $-0,47$ & 0,21 \\
\hline Qualified workers in agric./fish & $-3,80$ & $-0,88$ & $-2,91$ & $-4,03$ & $-1,01$ & $-3,02$ \\
\hline Machine Operators/Assemblers & $-2,21$ & $-0,09$ & $-2,13$ & $-1,64$ & $-0,13$ & $-1,51$ \\
\hline Production/Craft & $-6,19$ & $-8,74$ & 2,55 & $-1,25$ & $-1,32$ & 0,08 \\
\hline Retail sale/Service occup. & 4,58 & 5,30 & $-0,72$ & 2,62 & 0,99 & 1,63 \\
\hline Low-skilled service workers & 0,13 & $-1,54$ & 1,67 & 1,74 & 0,94 & 0,80 \\
\hline
\end{tabular}

Notes: The first column corresponds to the average wage of each major occupation in WSS 1995. The rest of the table uses LFS By sub period the first column corresponds to the change in the share of private sector employment by occupation, the second and the third are computed using a shift share analysis (Goos and Manning (2007)) 
Table 3: Intensity of Different Tasks by Broad Occupational Categories

\begin{tabular}{l|c|cc}
\hline \hline Occupational groups & Abstract intensity & Routine intensity & Service intensity \\
\hline \hline Managers/Prof/Tecn & 0.39 & 0.26 & 0.35 \\
Clerical/Civil servants & 0.28 & 0.33 & 0.38 \\
Retail sale/Service occup. & 0.24 & 0.38 & 0.38 \\
Qualified workers in agric./fish & 0.30 & 0.49 & 0.21 \\
Production/Craft, non-constr. & 0.27 & 0.57 & 0.16 \\
Machine operators/Assemblers & 0.26 & 0.51 & 0.24 \\
Low-skilled service workers & 0.17 & 0.58 & 0.25 \\
\hline \hline
\end{tabular}

Note: The intensities of the three tasks for each occupation sum up to one. They are relative task intensities. 
Table 4: The effect of task intensities on changes in share of employment. Dependent variable: Change in share of employment (\% points)

\begin{tabular}{|c|c|c|c|}
\hline Independent variables & $(1)$ & $(2)$ & (3) \\
\hline & $1997-2012$ & $1997-2007$ & Interacting effects \\
\hline $\begin{array}{l}\text { Abstract intensity } \\
\text { Abstract intensity * } \\
\text { Dummy period (2012- } \\
\text { 2007) }\end{array}$ & $\begin{array}{l}-0.446 \\
(3.599)\end{array}$ & $\begin{array}{l}-2.551 \\
(2.851)\end{array}$ & $\begin{array}{c}-2.551 \\
(2.855) \\
3.148 \\
(3.757) \\
\end{array}$ \\
\hline $\begin{array}{l}\text { Routine intensity } \\
\text { Routine intensity } * \\
\text { Dummy period ( } 2012 \text { - } \\
2007)\end{array}$ & $\begin{array}{l}-1.850 \\
(1.582)\end{array}$ & $\begin{array}{c}1.733 \\
(1.838)\end{array}$ & $\begin{array}{c}1.733 \\
(1.840) \\
-5.780^{* *} \\
(2.586) \\
\end{array}$ \\
\hline $\begin{array}{l}\text { Service intensity } \\
\text { Service intensity } * \\
\text { Dummy period (2012- } \\
2007)\end{array}$ & $\begin{array}{l}3.601 * * \\
(1.549)\end{array}$ & $\begin{array}{l}-1.743 \\
(2.381)\end{array}$ & $\begin{array}{c}-1.743 \\
(2.384) \\
8.590 * * * \\
(3.199) \\
\end{array}$ \\
\hline Routinization index & $\begin{array}{c}0.293 \\
(0.296)\end{array}$ & $\begin{array}{l}-0.290 \\
(0.250)\end{array}$ & $\begin{array}{c}0.250 \\
(0.181)\end{array}$ \\
\hline $\begin{array}{l}\text { Routinization index * } \\
\text { Dummy period (2012- } \\
2007)\end{array}$ & & & $\begin{array}{c}-0.908^{* * *} \\
(0.334)\end{array}$ \\
\hline Observations & 70 & 86 & 156 \\
\hline
\end{tabular}

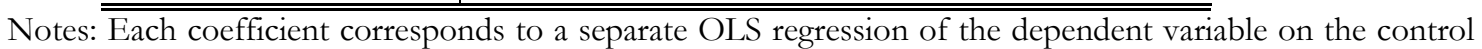
variables and a constant. Robust standard errors in parentheses. ${ }^{* * *}$ significant at $1 \%$ level, $* *$ significant at $5 \%$ level, * significant at $10 \%$ level. Number of observations is the number of occupations at ISCO88 3 digits level.. These estimations include also period time dummies not reported here. All estimations are weighted by the weight of employment of each ISCO88 3 digits occupation in total employment. 
Table 5: The effect of task intensities on changes in average age. Dependent variable: Change in average age

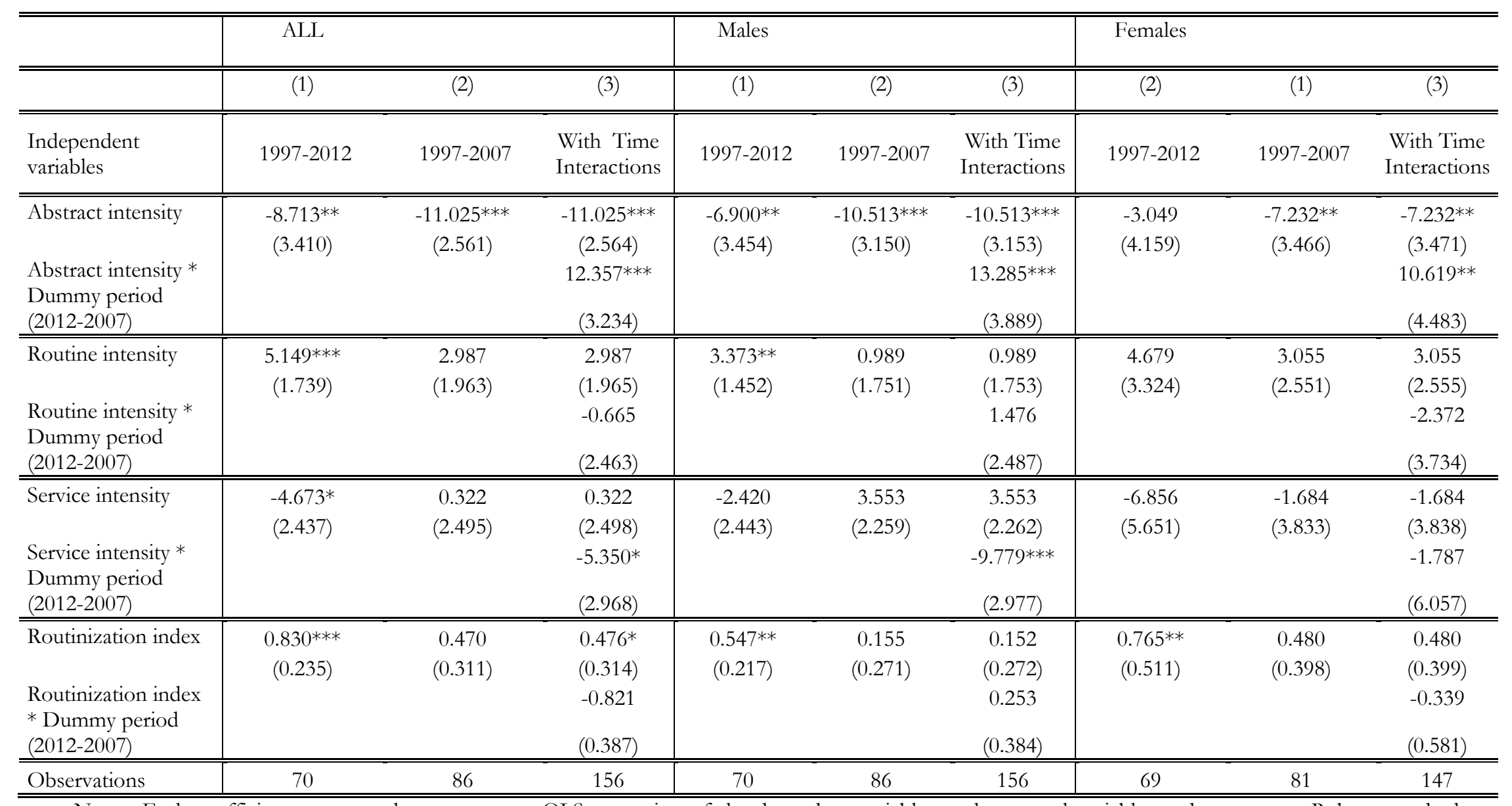

Notes: Each coefficient corresponds to a separate OLS regression of the dependent variable on the control variables and a constant. Robust standard errors in parentheses. *** significant at $1 \%$ level, ** significant at $5 \%$ level, * significant at $10 \%$ level. Number of observations is the number of occupations at ISCO 88 digits level. These estimations include also period time dummies not reported here. All estimations are weighted by the weight of employment of each ISCO88 3 digits occupation in total employment. 
Table 6: The effect of task intensities on changes in share of employment in 16-30 years age group.

Dep. variable: Change in share of workers in 16-30 years age group (\% points)

\begin{tabular}{|c|c|c|c|c|c|c|c|c|c|}
\hline & \multicolumn{3}{|l|}{ ALL } & \multicolumn{3}{|l|}{ Males } & \multicolumn{3}{|l|}{ Females } \\
\hline & $(1)$ & (2) & (3) & $(1)$ & (2) & (3) & (1) & $(2)$ & (3) \\
\hline $\begin{array}{l}\text { Independent } \\
\text { Variables }\end{array}$ & $1997-2012$ & $1997-2007$ & $\begin{array}{l}\text { With Time } \\
\text { Interactions }\end{array}$ & $1997-2012$ & $1997-2007$ & $\begin{array}{c}\text { With Time } \\
\text { Interactio } \\
\text { ns }\end{array}$ & $1997-2012$ & $1997-2007$ & $\begin{array}{l}\text { With Time } \\
\text { Interactions }\end{array}$ \\
\hline Abstract intensity & $\begin{array}{c}37.053^{* * *} \\
(13.785)\end{array}$ & $\begin{array}{l}32.150^{* * *} \\
(10.192)\end{array}$ & $\begin{array}{l}32.150^{* * *} \\
(10.207)\end{array}$ & $\begin{array}{c}49.359 * * * \\
(9.579)\end{array}$ & $\begin{array}{c}44.199 * * * \\
(11.120)\end{array}$ & $\begin{array}{c}44.199 * * * \\
(11.134)\end{array}$ & $\begin{array}{c}7.538 \\
(17.837)\end{array}$ & $\begin{array}{c}-0.761 \\
(12.673)\end{array}$ & $\begin{array}{c}-0.761 \\
(12.692)\end{array}$ \\
\hline $\begin{array}{l}\text { Abstract intensity * Dummy } \\
\text { period (2012-2007) }\end{array}$ & & & $\begin{array}{c}-28.936 * * \\
(13.626)\end{array}$ & & & $\begin{array}{l}-42.819^{* * *} \\
(15.185)\end{array}$ & & & $\begin{array}{c}0.519 \\
(16.772)\end{array}$ \\
\hline Routine intensity & $\begin{array}{c}-21.590^{* * *} \\
(7.019)\end{array}$ & $\begin{array}{l}-4.450 \\
(6.846)\end{array}$ & $\begin{array}{l}-4.450 \\
(6.855)\end{array}$ & $\begin{array}{c}-27.413^{* * *} \\
(5.042)\end{array}$ & $\begin{array}{l}-5.172 \\
(7.052)\end{array}$ & $\begin{array}{l}-5.172 \\
(7.061)\end{array}$ & $\begin{array}{l}-11.402 \\
(14.514)\end{array}$ & $\begin{array}{c}-0.778 \\
(11.839)\end{array}$ & $\begin{array}{l}-0.778 \\
(11.856)\end{array}$ \\
\hline $\begin{array}{l}\text { Routine intensity * Dummy } \\
\text { period (2012-2007) }\end{array}$ & & & $\begin{array}{l}-13.561 \\
(10.003)\end{array}$ & & & $\begin{array}{l}-17.179 * \\
(10.241)\end{array}$ & & & $\begin{array}{c}-5.097 \\
(18.598)\end{array}$ \\
\hline Service intensity & $\begin{array}{l}19.269 \\
(11.633)\end{array}$ & $\begin{array}{l}-8.376 \\
(8.931)\end{array}$ & $\begin{array}{l}-8.376 \\
(8.943)\end{array}$ & $\begin{array}{l}23.227 * * \\
(10.391)\end{array}$ & $\begin{array}{l}-13.168 \\
(8.270)\end{array}$ & $\begin{array}{l}-13.168 \\
(8.280)\end{array}$ & $\begin{array}{l}16.620 \\
(24.724)\end{array}$ & $\begin{array}{c}1.764 \\
(20.720)\end{array}$ & $\begin{array}{c}1.764 \\
(20.751)\end{array}$ \\
\hline $\begin{array}{l}\text { Service intensity } * \text { Dummy } \\
\text { period }(2012-2007)\end{array}$ & & & $\begin{array}{c}38.470 * * * \\
(12.082)\end{array}$ & & & $\begin{array}{c}52.225^{* * *} \\
(10.691)\end{array}$ & & & $\begin{array}{c}8.792 \\
(31.839)\end{array}$ \\
\hline Routinization index & $\begin{array}{c}-3.55 . * * * \\
(1.05)\end{array}$ & $\begin{array}{l}-0.718 \\
(1.035)\end{array}$ & $\begin{array}{l}-0.718 \\
(1.074)\end{array}$ & $\begin{array}{c}-4.370^{* * *} \\
(0.752)\end{array}$ & $\begin{array}{l}-0.772 \\
(1.103)\end{array}$ & $\begin{array}{l}-0.772 \\
(0.105)\end{array}$ & $\begin{array}{l}-2.024 \\
(2.268)\end{array}$ & $\begin{array}{l}-0.156 \\
(1.844)\end{array}$ & $\begin{array}{l}-0.156 \\
(1.843)\end{array}$ \\
\hline Routin. index * (2012-2007) & & & $\begin{array}{l}-2.248^{*} \\
(1.568)\end{array}$ & & & $\begin{array}{l}-2.836 * \\
(1.586)\end{array}$ & & & $\begin{array}{l}-0.972 \\
(2.919)\end{array}$ \\
\hline Observations & 68 & 86 & 154 & 67 & 84 & 152 & 63 & 78 & 140 \\
\hline
\end{tabular}

Notes: Each coefficient corresponds to a separate OLS regression of the dependent variable on the control variables and a constant. Robust standard errors in parentheses. *** significant at 1\% level, ** significant at 5\% level, * significant at 10\% level. Number of observations is the number of occupations at ISCO88 3 digits level. In the estimations for the pool of periods 1997-2007 and 2007-2012, period 1997-2007 is the reference period. These estimations include also period time dummies not reported here. All estimations are weighted by the weight of employment of each ISCO88 3 digits occupation in total employment 
Table7: The effect of task intensities on changes in share of employment in 31-45 years age group.

Dep. variable: Change in share of workers in $31-45$ years age group $(\%$ points)

\begin{tabular}{|c|c|c|c|c|c|c|c|c|c|}
\hline & (1) & (2) & (3) & $(1)$ & (2) & (3) & $(1)$ & $(2)$ & (3) \\
\hline $\begin{array}{l}\text { Independent } \\
\text { variables }\end{array}$ & $1997-2012$ & $1997-2007$ & $\begin{array}{l}\text { With Time } \\
\text { Interactions }\end{array}$ & 1997-2012 & $1997-2007$ & $\begin{array}{l}\text { With Time } \\
\text { Interactions }\end{array}$ & $1997-2012$ & $1997-2007$ & $\begin{array}{l}\text { With Time } \\
\text { Interactions }\end{array}$ \\
\hline $\begin{array}{l}\text { Abstract intensity } \\
\text { Abstract intensity } \\
\text { * Dummy period } \\
\text { (2012-2007) }\end{array}$ & $\begin{array}{l}-27.423 \\
(18.216)\end{array}$ & $\begin{array}{c}-15.176^{*} \\
(8.379)\end{array}$ & $\begin{array}{c}-15.176^{*} \\
(8.389) \\
11.957 \\
(14.588)\end{array}$ & $\begin{array}{c}-42.406^{* *} \\
(16.772)\end{array}$ & $\begin{array}{c}-36.823^{* * *} \\
(11.691)\end{array}$ & $\begin{array}{c}-36.823^{* * *} \\
(11.705) \\
41.759^{* *} \\
(18.796) \\
\end{array}$ & $\begin{array}{c}-5.208 \\
(19.316)\end{array}$ & $\begin{array}{c}6.797 \\
(9.997)\end{array}$ & $\begin{array}{c}6.797 \\
(10.008) \\
-8.324 \\
(20.452)\end{array}$ \\
\hline $\begin{array}{l}\text { Routine intensity } \\
\text { Routine intensity } \\
\text { * Dummy period } \\
\text { (2012-2007) }\end{array}$ & $\begin{array}{l}14.413 \\
(9.910)\end{array}$ & $\begin{array}{c}0.806 \\
(4.530)\end{array}$ & $\begin{array}{c}0.806 \\
(4.536) \\
11.384 \\
(9.238) \\
\end{array}$ & $\begin{array}{c}26.632^{* * *} \\
(8.986)\end{array}$ & $\begin{array}{c}11.009 * \\
(6.489)\end{array}$ & $\begin{array}{c}11.009 * \\
(6.497) \\
3.945 \\
(10.925) \\
\end{array}$ & $\begin{array}{c}-1.716 \\
(16.463)\end{array}$ & $\begin{array}{c}-14.035 \\
(9.704)\end{array}$ & $\begin{array}{l}-14.035 \\
(9.715) \\
25.859 \\
(17.153) \\
\end{array}$ \\
\hline $\begin{array}{l}\text { Service intensity } \\
\text { Service intensity * } \\
\text { Dummy period } \\
(2012-2007)\end{array}$ & $\begin{array}{l}-11.447 \\
(14.517)\end{array}$ & $\begin{array}{c}6.212 \\
(5.008)\end{array}$ & $\begin{array}{c}6.212 \\
(5.014) \\
-25.903^{* *} \\
(11.326) \\
\end{array}$ & $\begin{array}{l}-25.595^{*} \\
(13.999)\end{array}$ & $\begin{array}{l}-0.722 \\
(6.499)\end{array}$ & $\begin{array}{c}-0.722 \\
(6.507) \\
-29.258^{* *} \\
(11.499) \\
\end{array}$ & $\begin{array}{c}5.919 \\
(26.248)\end{array}$ & $\begin{array}{c}21.267 \\
(16.550)\end{array}$ & $\begin{array}{c}21.267 \\
(16.568) \\
-41.498 \\
(25.863) \\
\end{array}$ \\
\hline $\begin{array}{l}\begin{array}{l}\text { Routinization } \\
\text { index }\end{array} \\
\text { Routinization } \\
\text { index * Dummy } \\
\text { period (2012- } \\
\text { 2007) } \\
\end{array}$ & $\begin{array}{c}2.39 * \\
(1.547)\end{array}$ & $\begin{array}{c}0.116 \\
(0.691)\end{array}$ & $\begin{array}{c}0.116 \\
(0.698) \\
1.923 \\
\\
(1.459) \\
\end{array}$ & $\begin{array}{c}4.225^{* *} \\
(1.378)\end{array}$ & $\begin{array}{l}1.662^{*} \\
(1.011)\end{array}$ & $\begin{array}{c}1.662 \\
(1.012) \\
0.799 \\
(1.689) \\
\end{array}$ & $\begin{array}{l}-0.074 \\
(2.612)\end{array}$ & $\begin{array}{l}-2.198 \\
(1.500)\end{array}$ & $\begin{array}{l}-2.198 \\
(1.502) \\
4.210^{*} \\
\\
(2.708) \\
\end{array}$ \\
\hline Observations & 70 & 86 & 156 & 70 & 86 & 156 & 65 & 78 & 144 \\
\hline
\end{tabular}

Notes: Each coefficient corresponds to a separate OLS regression of the dependent variable on the control variables and a constant. Robust standard errors in parentheses. *** significant at $1 \%$ level, ** significant at $5 \%$ level, * significant at 10\% level. Number of observations is the number of occupations at ISCO 883 digits level. In the estimations for the pool of periods 1997-2007 and 2007-2012, period 1997-2007 is the reference period. These estimations include also period time dummies not reported here. All estimations are weighted by the weight of employment of each ISCO88 3 digits occupation in total employment 
Table 8: The effect of task intensities on changes in share of employment in 46-64 years age group.

Dep. variable: Change in share of workers in $46-64$ years age group $(\%$ points)

\begin{tabular}{|c|c|c|c|c|c|c|c|c|c|}
\hline & (1) & (2) & (3) & (1) & (2) & (3) & (1) & (2) & (3) \\
\hline $\begin{array}{l}\text { Independent } \\
\text { variables }\end{array}$ & 1997-2012 & $1997-2007$ & $\begin{array}{l}\text { With Time } \\
\text { Interactions }\end{array}$ & 1997-2012 & $1997-2007$ & $\begin{array}{l}\text { With Time } \\
\text { Interactions }\end{array}$ & 1997-2012 & $1997-2007$ & $\begin{array}{l}\text { With Time } \\
\text { Interactions }\end{array}$ \\
\hline $\begin{array}{l}\text { Abstract intensity } \\
\text { Abstract intensity * } \\
\text { Dummy period } \\
(2012-2007)\end{array}$ & $\begin{array}{c}-9.608 \\
(15.114)\end{array}$ & $\begin{array}{l}-16.974 \\
(10.675)\end{array}$ & $\begin{array}{c}-16.974 \\
(10.688) \\
17.042 \\
(13.041) \\
\end{array}$ & $\begin{array}{c}-7.333 \\
(15.553)\end{array}$ & $\begin{array}{c}-7.470 \\
(11.250)\end{array}$ & $\begin{array}{c}-7.470 \\
(11.263) \\
1.134 \\
(14.620) \\
\end{array}$ & $\begin{array}{c}-1.898 \\
(17.545)\end{array}$ & $\begin{array}{c}-5.064 \\
(13.634)\end{array}$ & $\begin{array}{c}-5.064 \\
(13.640) \\
6.323 \\
(20.145) \\
\end{array}$ \\
\hline $\begin{array}{l}\text { Routine intensity } \\
\text { Routine intensity * } \\
\text { Dummy period } \\
(2012-2007)\end{array}$ & $\begin{array}{c}7.127 \\
(7.450)\end{array}$ & $\begin{array}{c}3.644 \\
(6.548)\end{array}$ & $\begin{array}{l}3.644 \\
(6.556) \\
2.100 \\
(7.600) \\
\end{array}$ & $\begin{array}{c}0.853 \\
(7.660)\end{array}$ & $\begin{array}{l}-5.859 \\
(5.800)\end{array}$ & $\begin{array}{l}-5.859 \\
(5.807) \\
13.194^{*} \\
(7.382) \\
\end{array}$ & $\begin{array}{c}5.728 \\
(12.587)\end{array}$ & $\begin{array}{l}11.296 \\
(8.740)\end{array}$ & $\begin{array}{l}11.296 \\
(8.745) \\
-17.453 \\
(14.455) \\
\end{array}$ \\
\hline $\begin{array}{l}\text { Service intensity } \\
\text { Service intensity * } \\
\text { Dummy period } \\
(2012-2007)\end{array}$ & $\begin{array}{l}-7.784 \\
(9.915)\end{array}$ & $\begin{array}{c}2.163 \\
(8.105)\end{array}$ & $\begin{array}{r}2.163 \\
(8.115) \\
-12.481 \\
(9.611)\end{array}$ & $\begin{array}{c}2.381 \\
(10.036)\end{array}$ & $\begin{array}{c}13.946 * \\
(7.270)\end{array}$ & $\begin{array}{c}13.946^{*} \\
(7.279) \\
-22.912^{* *} \\
(9.907)\end{array}$ & $\begin{array}{c}-9.623 \\
(20.305)\end{array}$ & $\begin{array}{l}-17.524 \\
(12.834)\end{array}$ & $\begin{array}{c}-17.524 \\
(12.840) \\
27.782 \\
(21.877)\end{array}$ \\
\hline $\begin{array}{l}\text { Routinization index } \\
\text { Routinization index } \\
\text { * Dummy period } \\
(2012-2007)\end{array}$ & $\begin{array}{c}1.148 \\
(1.154)\end{array}$ & $\begin{array}{c}0.601 \\
(1.024)\end{array}$ & $\begin{array}{c}0.601 \\
(1.026) \\
0.292 \\
(1.183)\end{array}$ & $\begin{array}{c}0.157 \\
(1.181)\end{array}$ & $\begin{array}{l}-0.893 \\
(0.898)\end{array}$ & $\begin{array}{l}-0.893 \\
(0.899) \\
2.027 * \\
(1.136)\end{array}$ & $\begin{array}{c}0.937 \\
(1.931)\end{array}$ & $\begin{array}{c}1.816 \\
(1.349)\end{array}$ & $\begin{array}{c}1.816 \\
(1.350) \\
-2.734 \\
(2.245)\end{array}$ \\
\hline Observations & 70 & 86 & 156 & 69 & 84 & 153 & 56 & 67 & 130 \\
\hline
\end{tabular}

Notes: Each coefficient corresponds to a separate OLS regression of the dependent variable on the control variables and a constant. Robust standard errors in parentheses. *** significant at 1\% level, ** significant at 5\% level, * significant at 10\% level. Number of observations is the number of occupations at ISCO 883 digits level. Estimations include also period time dummies not reported here. All estimations are weighted by the weight of employment of each ISCO88 3 digits occupation in total employment. 